\title{
Implementasi Model Pembelajaran Berbasis Proyek untuk Meningkatkan Hasil Belajar IPA
}

\author{
Indah Iswantari \\ Guru SMP Negeri 2 Kayangan, Kabupaten Lombok Utara - Provinsi NTB \\ *Corresponding Author. Email: jaelaniindahza@gmail.com
}

\begin{abstract}
The purpose of this study is to improve science learning outcomes through the implementation of project-based learning models. The research method used is classroom action research. The number of subjects in this study were 21 students. The research instrument used was a learning outcome test. Meanwhile, the technical analysis of the data in this study used qualitative and quantitative descriptive techniques. The results of this study indicate that the application of a project-based learning model can improve science learning outcomes in class 7.2 students of SMPN 2 Kayangan for the 2020/2021 school year. The learning outcomes of students before the implementation of projectbased learning (cycle I) were very low, where the classical completeness score was only $33.3 \%$. After taking action by applying the project-based learning model in cycle II, the classical completeness score was $90.5 \%$ where 19 students scored above the KKM.
\end{abstract}

\begin{abstract}
Abstrak: Tujuan penelitian ini adalah untuk meningkatkan hasil belajar IPA melalui implementasi model pembelajaran berbasis proyek. Metode penelitian yang digunakan adalah penelitian tindakan kelas. Jumlah subyek dalam penelitian ini sebanyak 21 peserta didik. Instrumen penelitian yang digunakan adalah tes hasil belajar. Sedangkan teknis analisis data pada penelitian ini menggunakan teknis deskriptif kualitatif dan kuantitatif. Hasil penelitian ini menunjukkan bahwa penerapan model pembelajaran berbasis proyek dapat meningkatkan hasil belajar IPA pada peserta didik kelas 7.2 SMPN 2 Kayangan tahun pelajaran 2020/2021. Hasil belajar peserta didik sebelum penerapan pembelajaran berbasis proyek (siklus I) sangat rendah, di mana diperoleh nilai ketuntasan klasikal hanya 33,3 \%. Setelah dilakukan tindakan dengan menerapkan model pembelajaran berbasis proyek pada siklus II diperoleh nilai ketuntasan klasikal sebesar 90,5 \% dimana 19 orang peserta didik yang memperoleh nilai di atas KKM.
\end{abstract}

Article History

Received: 10-08-2021

Revised: 25-08-2021

Accepted: 15-09-2021

Published: 05-10-2021

\section{Key Words:}

Project-Based Learning, Learning Outcomes, Science.

\section{Sejarah Artikel}

Diterima: 10-08-2021

Direvisi: 25-08-2021

Disetujui: 15-09-2021

Diterbitkan: 05-10-2021

\section{Kata Kunci:}

Pembelajaran Berbasis

Proyek, Hasil Belajar IPA.

How to Cite: Iswantari, I. (2021). Implementasi Model Pembelajaran Berbasis Proyek untuk Meningkatkan Hasil Belajar IPA. Jurnal Paedagogy, 8(4), 490-496. doi:https://doi.org/10.33394/jp.v8i4.4126

dc. https://doi.org/10.33394/jp.v8i4.4126

This is an open-access article under the CC-BY-SA License.

\section{Pendahuluan}

Pendidikan merupakan kebutuhan utama setiap orang yang harus dipenuhi. Pendidikan juga merupakan tonggak kemajuan suatu bangsa karena dengan meningkatnya pendidikan maka suatu bangsa bisa dikatakan maju. Majunya pendidikan suatu bangsa tidak terlepas dari peran pendidik yang dapat melahirkan generasi-generasi cerdas dan hebat yang nantinya akan dapat mengemban tugas bagi bangsa dan negaranya sendiri (Tilaar, 2001; Suarni, 2021).

Pendidikan di Indonesia saat ini sedang mengalami perubahan yang cukup signifikan di berbagai bidangnya. Perubahan ini secara langsung maupun tidak langsung tentu saja berimbas kepada guru dan peserta didik dalam proses pembelajaran. Guru dituntut untuk lebih kreatif dalam mengembangkan ide-ide pembelajaran yaitu melakukan transisi pembelajaran dari metode pembelajaran yang cenderung membosankan ke metode 
pembelajaran yang lebih menarik. Dengan tersebarnya inovasi ilmu pengetahuan secara cepat, maka upaya pembaharuan dalam pembelajaran sangat perlu untuk dilakukan agar dapat menciptakan suasana belajar yang menarik dan kondusif, khususnya pada mata pelajaran Ilmu Pengetahuan Alam. Hal tersebut menjadi sangat perlu dilakukan karena adanya indikasi yang menunjukkan bahwa beberapa guru mata pelajaran Ilmu Pengetahuan Alam kurang dapat menciptakan suasana belajar yang menyenangkan dan menarik sehingga aktivitas peserta didik dalam belajar menjadi rendah.

Agar guru dapat mengajar dengan menggunakan berbagai metode mengajar yang bervariasi, maka perlu dikembangkan model-model pembelajaran baru agar peserta didik terhindar dari rasa bosan dalam mengikuti kegiatan pembelajaran. Agar peserta didik terlatih dan termotivasi dalam belajar hendaknya guru mengajar menggunakan model pembelajaran yang dapat meningkatkan aktivitas belajar peserta didik. Pendidikan saat ini lebih mengarah kepada pola pendidikan yang modern dan kreatif, di mana guru tidak lagi menjadi center pembelajaran namun guru memberikan kesempatan kepada peserta didik untuk melakukan eksplorasi dalam menemukan atau menciptakan karya dalam pembelajaran.

Berdasarkan hasil observasi proses pembelajaran kelas 7.2 pada mata pelajaran IPA di SMPN 2 Kayangan, diperoleh hasil belajar peserta didik yang cenderung lebih rendah. Hal ini tentu saja disebabkan masih adanya beberapa guru yang menggunakan metode mengajar yang bersifat monoton sehingga peserta didik menjadi cepat bosan dan tidak termotivasi untuk belajar yang pada akhirnya tentu saja berpengaruh pada hasil belajar peserta didik. Menurut Aminah (2017), Abdiningsih, (2017), Fitriana, (2019) menjelaskan bahwa hasil belajar merupakan nilai pengetahuan yang diperoleh siswa pada akhir pembelajaran sehingga akan diketahui tingkat keberhasilan siswa dalam proses pembelajaran. Hasil belajar juga mejadi tolak ukur untuk mengetahui keberhasilan siswa dalam memahami materi pembelajaran (Purwati, 2019; Nashirotun, 2020; Suarni et al., 2021).

Salah satu alternatif yang sangat relevan dan cukup sederhana untuk diterapkan dalam pembelajaran Ilmu Pengetahuan Alam (IPA) adalah model Pembelajaran Berbasis Proyek ( PjBL ). Dengan menerapkan model pembelajaran berbasis proyek diharapkan peserta didik lebih aktif terlibat dalam kegiatan pembelajaran (Lapase, 2021). Untuk mendorong peserta didik menghasilkan karya kontekstual baik secara individual maupun secara kolaboratif maka dirasa sangatlah tepat jika menggunakan model pembelajaran berbasis proyek. Dengan demikian model pembelajaran berbasis proyek diduga dapat meningkatkan aktivitas belajar peserta didik, sehingga diperkirakan daya serap peserta didik tentang materi yang telah dipelajari sesuai dengan yang diharapkan.

Model PjBL adalah sebuah model pembelajaran yang menggunakan proyek (kegiatan) sebagai inti pembelajaran. Pembelajaran PjBL terbukti dapat meningkatkan kreativitas siswa (Afriana, 2016). Penekanan pembelajaran berbasis proyek terletak pada aktivitas peserta didik untuk memecahkan masalah dengan menerapkan keterampilan meneliti, menganalisis, membuat sampai dengan mempresentasikan produk pembelajaran berdasarkan pengalaman nyata (Mulyana, 2020).

Langkah-langkah pembelajaran dalam Project Based Learning (PjBL) sebagaimana yang dikembangkan oleh The George Lucas Foundation dalam Pradita, (2015) terdiri dari: a). Dimulai dengan pertanyaan yang essensial, mengambil topik yang sesuai dengan realitas dunia nyata dan dimulai dengan sebuah investigasi mendalam. b). Perencanaan aturan pengerjaan proyek, berisi tentang aturan main serta pemilihan aktivitas yang dapat mendukung dalam menjawab pertanyaan esensial, dengan cara mengintergrasikan berbagai subjek yang mungkin, serta mengetahui alat dan bahan yang dapat diakses untuk membantu 
penyelesaian proyek. c). Membuat jadwal aktivitas secara kolaboratif dalam menyelesaikan proyek. d). Guru memonitoring perkembangan proyek siswa dengan cara menfasilitasi siswa dalam setiap proses penyelesaian proyek. e). Penilaian hasil kerja siswa untuk membantu peserta didik dalam mengukur ketercapaian standar, berperan dalam mengevaluasi kemajuan masing-masing peserta didik, memberi umpan balik tentang tingkat pemahaman yang sudah dicapai peserta didik, membantu peserta didik dalam menyusun strategi pembelajaran berikutnya. f). Evaluasi pengalaman belajar siswa

Selanjutnya Hosnan dalam Rati (2017) menerangkan bahwa pembelajaran berbasis proyek memiliki potensi yang besar untuk memberikan pengalaman belajar yang lebih menarik dan bermakna bagi siswa. Sedangkan menurut Wijanarko (2017) Penerapan model pembelajaran berbasis proyek $(\mathrm{PjBL})$ membuat siswa aktif bekerjasama dengan kelompoknya saat mengerjakan proyek serta membuat kegiatan belajar menjadi lebih menyenangkan, menghibur, dan bermakna. Menurut Fikriyah (2015). Kelemahan-kelemahan model pembelajaran berbasis proyek (project based learning), antara lain: penerapan project based learning membutuhkan banyak waktu dalam menyelesaikan masalah, kendala ini muncul manakala pembelajaran berlangsung hanya satu jam pelajaran saja (45 menit) sedangkan proses pembelajaran harus melalui enam fase, sehingga setiap fase dalam pembelajaran pun berlangsung serba cepat dan singkat. Selain itu, beberapa siswa mengalami kesulitan selama proses pembelajaran akibat memiliki kelemahan dalam memahami percobaan dan mengumpulkan informasi, padahal model project based learning mempersyaratkan siswa harus mampu secara mandiri memperoleh informasi melalui sumber-sumber informasi yang tersedia.

Adapun tujuan penelitian ini adalah menganalisis pelaksanaan model pembelajaran berbasis proyek untuk meningkatkan hasil belajar peserta didik pada mata pelajaran IPA di kelas 7.2 SMP Negeri 2 Kayangan. Oleh karena itu, penelitian ini menjadi penting, khususnya pada mata pelajaran IPA. Hasil penelitian ini diharapkan dapat menjadi acuan dalam usaha perbaikan suasana pembelajaran sehingga siswa lebih termotivasi untuk belajar dan mendapatkan hasil yang maksimal.

\section{Metode Penelitian}

Metode penelitian ini menggunakan penelitian tindakan kelas yang dilakukan dalam 2 siklus. Subyek dalam penelitian ini adalah siswa kelas 7.2 SMP Negeri 2 Kayangan yang melibatkan 21 peserta didik, terdiri dari 10 orang perempuan dan 11 orang laki-laki. Penelitian ini dilakukan di SMP Negeri 2 Kayangan yang dilaksanakan di semester II dari bulan Januari sampai bulan Februari tahun pelajaran 2020/2021. Obyek penelitian ini adalah meningkatkan aktivitas belajar kelas 7.2 pada materi Sistem Organisasi Kehidupan Makhluk Hidup. Instrumen penelitian yang digunakan adalah tes hasil belajar bentuk pilihan ganda berjumlah 25 butir soal. Sedangkan teknis analisis data pada penelitian ini menggunakan teknis deskriptif kualitatif dan kuantitatif.

Untuk meningkatkan keaktifan peserta didik dalam menggunakan model pembelajaran project based learning ini, maka langkah-langkah yang harus dilakukan adalah: pembelajaran dimulai dengan pertanyaan esensial, yaitu pertanyaan yang dapat memberi penugasan siswa dalam melakukan suatu aktivitas. Menyusun perencanaan yang dilakukan secara kolaboratif antara guru dan siswa. Guru dan siswa secara kolaboratif menyusun jadwal kegiatan dalam menyelesaikan proyek. Aktivitas pada tahap ini antara lain: membuat jadwal untuk menyelesaikan proyek, (2) menentukan waktu akhir penyelesaian proyek, (3) membawa siswa agar merencanakan cara yang baru, (4) membimbing siswa ketika mereka 
membuat cara yang tidak berhubungan dengan proyek, dan (5) meminta siswa untuk membuat penjelasan (alasan) tentang cara pemilihan waktu. Guru bertanggung jawab untuk memantau kegiatan siswa selama menyelesaikan proyek. Pemantauan dilakukan dengan cara memfasilitasi siswa pada setiap proses. Penilaian dilakukan untuk membantu guru dalam mengukur ketercapaian standar kompetensi, berperan dalam mengevaluasi kemajuan masingmasing siswa, memberi umpan balik tentang tingkat pemahaman yang sudah dicapai siswa, membantu guru dalam menyusun strategi pembelajaran berikutnya. Pada akhir proses pembelajaran, guru dan siswa melakukan refleksi terhadap kegiatan dan hasil proyek yang sudah dijalankan. Proses refleksi dilakukan baik secara individu maupun kelompok. Pada tahap ini siswa diminta untuk mengungkapkan perasaan dan pengalamannya selama menyelesaikan proyek.

\section{Hasil Penelitian dan Pembahasan}

Tindakan penelitian ini dilakukan melalui 2 siklus yaitu siklus I dan Siklus II. Tahapan-tahapan yang dilakukan pada siklus I adalah : Perencanaan yaitu menyiapkan silabus, menyiapkan RPP, dan menyiapkan soal evaluasi. Pelaksanaan yaitu guru memberikan materi kepada peserta didik secara garis besar. Observasi yaitu memberikan soal evaluasi, dan Refleksi. Sedangkan pada siklus II guru menerapkan model pembelajaran berbasis proyek. Langkah-langkah yang dilakukan dalam penerapan model pembelajaran berbasis proyek adalah guru membagi peserta didik kelas 7.2 menjadi 4 kelompok, kemudian setiap kelompok dibagikan alat dan bahan yang digunakan dalam pembuatan proyek, guru memantau kegiatan siswa selama menyelesaikan proyek, terakhir guru dan siswa melakukan refleksi terhadap kegiatan dan hasil proyek yang sudah dijalankan.

Pada siklus I soal evaluasi diberikan untuk mengobservasi peserta didik guna mengetahui kemampuan awal yang dimiliki oleh peserta didik dalam pembelajaran tersebut. Sebelum memberikan soal evaluasi, guru terlebih dahulu memberikan motivasi terhadap peserta didik dengan memberikan penjelasan secara garis besar tentang materi Sistem Organisasi Kehidupan Makhluk Hidup, peserta didik disuruh membaca buku paket tentang materi tersebut, kemudian mengajukan beberapa pertanyaan terkait dengan materi tersebut, selanjutnya guru melakukan observasi dengan memberikan soal evaluasi yang sudah disiapkan. Observasi pembelajaran berlangsung di kelas yang dilakukan dengan memberikan soal evaluasi kepada peserta didik kelas 7.2 tentang materi Sistem Organisasi Kehidupan Makhluk Hidup. Soal evaluasi berupa soal pilihan ganda berjumlah 25 soal dengan bobot skor masing-masing soal adalah 1 sehingga jumlah skor 25 dengan nilai 100. Soal evaluasi ini digunakan untuk menghindari unsur penilaian subyektif terhadap peserta didik.

Berdasarkan hasil penilaian pada siklus I, dari keseluruhan peserta didik yang berjumlah 21 orang, hanya 7 orang yang memperoleh nilai tuntas $(33,3 \%)$ dan 14 orang memperoleh nilai tidak tuntas $(66,7 \%)$ atau di bawah Kriteria Ketuntasan Minimal (KKM). Kriteria ketuntasan minimal untuk mata pelajaran IPA kelas 7 adalah 72. Nilai rata-rata yang diperoleh pada siklus I adalah 66. Menurut DEPDIKNAS dalam Santoso, 2013 Salah satu prinsip penilaian adalah "mengunakan acuan kriteria, yakni menggunakan kriteria tertentu dalam menentukan kelulusan peserta didik. Kriteria paling rendah untuk menyatakan peserta didik mencapai ketuntasan dinamakan Kriteria Ketuntasan Minimal (KKM)".

Dari hasil observasi di atas membuktikan bahwa secara keseluruhan hasil belajar peserta didik kelas 7.2 sangatlah rendah karena belum mencapai persentase ketuntasan $85 \%$. Hasil evaluasi peserta didik kelas 7.2 dapat dilihat pada grafik di bawah ini: 


\section{Grafik Perolehan Hasil Belajar Pada Siklus I}

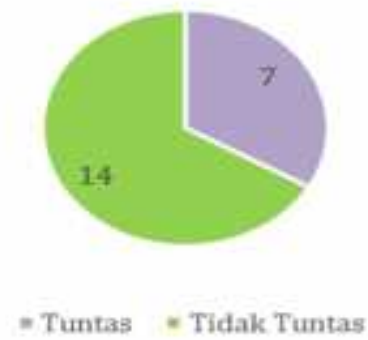

Berdasarkan grafik di atas, sangat jelas terlihat bahwa peserta didik kelas 7.2 SMP Negeri 2 Kayangan yang mengalami ketidaktuntasan dalam belajar sebanyak 14 orang. Dari hasil tersebut, terlihat bahwa pelaksanaan siklus I belum berhasil karena guru masih mengajar dengan metode yang cenderung membosankan sehingga peserta didik kurang menguasai pelajaran dan akhirnya hasil belajarnya rendah.

Dalam pelaksanaan siklus II, guru menerapkan model pembelajaran berbasis proyek dengan langkah-langkah yang sudah dijelaskan di atas. Setelah tindakan siklus II selesai dilaksanakan, guru memberikan tes evaluasi yaitu soal yang sama dengan soal evaluasi pada siklus I untuk mengetahui perbandingan hasil belajar sebelum pelaksanaan tindakan dengan sesudah pelaksanaan tindakan. Berdasarkan hasil penilaian pada siklus II, dari keseluruhan peserta didik kelas 7.2 yang berjumlah 21 orang, 19 orang yang memperoleh nilai tuntas $(90,5 \%)$ dan 2 orang yang memperoleh nilai tidak tuntas $(9,5 \%)$. Nilai rata-rata yang diperoleh adalah 83. Dari hasil tersebut, maka dapat dikatakan bahwa sebanyak 19 orang dari 21 orang memperoleh nilai di atas KKM dan 2 orang memperoleh nilai di bawah KKM, artinya perolehan hasil belajar keseluruhan kelas 7.2 pada siklus I ini termasuk pada kategori tuntas yaitu 90,5\%. Dikatakan tuntas karena memperoleh nilai rata-rata 83 (di atas KKM) dan persentase ketuntasan di atas $85 \%$. Perolehan hasil belajar kelas 7.2 pada siklus II dapat dilihat pada grafik di bawah:

Grafik Perolehan Hasil Belajar Pada Siklus II

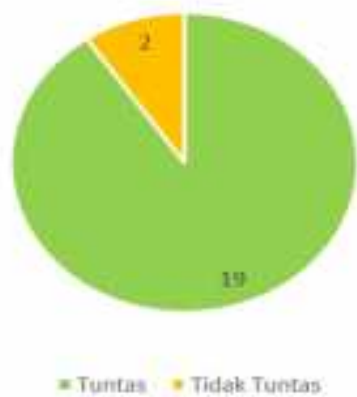

Penilaian Hasil Belajar oleh Pendidik berfungsi untuk memantau kemajuan belajar, memantau hasil belajar, dan mendeteksi kebutuhan perbaikan hasil belajar peserta didik secara berkesinambungan (Iswantari, 2019).

Berdasarkan hasil penelitian menggunakan model pembelajaran berbasis proyek yang telah dilaksanakan, hasil belajar peserta didik kelas 7.2 mengalami peningkatan. Hasil belajar peserta didik sebelum penerapan pembelajaran berbasis proyek sangat rendah, di mana diperoleh nilai ketuntasan klasikal hanya 33,3\%. Setelah dilakukan tindakan dengan 
menerapkan model pembelajaran berbasis proyek pada siklus II, diperoleh nilai ketuntasan klasikal sebesar 90,5\% dimana 19 orang peserta didik yang memperoleh nilai di atas KKM.

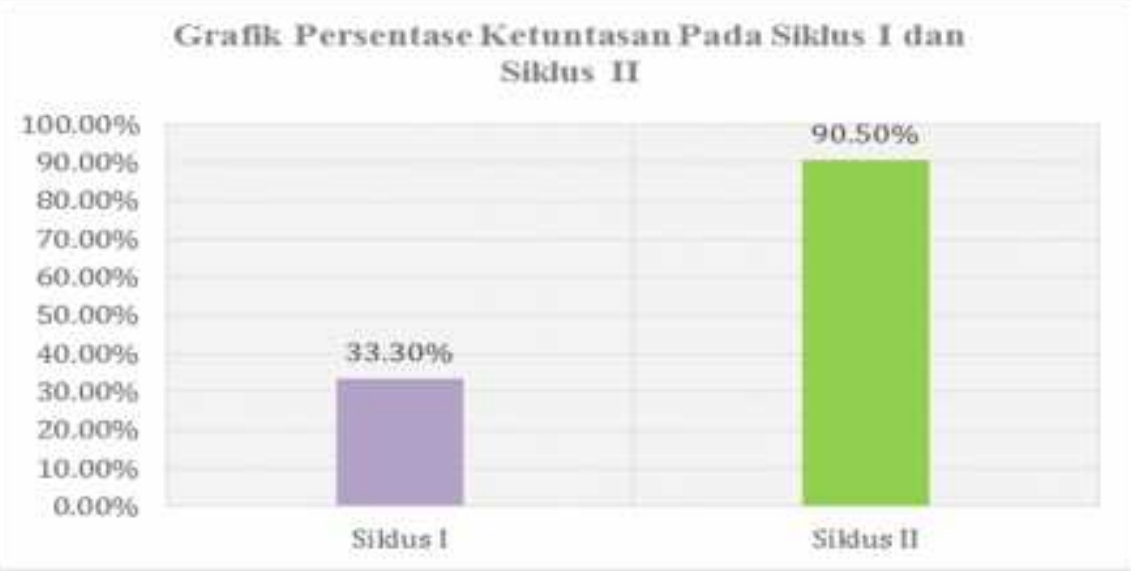

Penerapan model pembelajaran berbasis proyek dapat meningkatkan hasil belajar peserta didik, karena dalam pelaksanaannya peserta didik dituntut untuk semangat dan aktif dalam belajar baik secara individu maupun kelompok, sehingga setiap peserta didik dapat menguasai pelajaran. Jika peserta didik menguasai pelajaran, maka akan meningkatkan hasil belajarnya. Adapun hasil penelitian ini sejalan dengan penelitian Lapase (2021) yang menyimpulkan bahwa model pembelajaran berbasis proyek dapat meningkatkan hasil belajar matematika siswa.

\section{Kesimpulan}

Kesimpulan yang diperoleh dari hasil penelitian ini adalah penerapan model pembelajaran berbasis proyek dapat meningkatkan hasil belajar IPA pada peserta didik kelas 7.2 SMPN 2 Kayangan tahun pelajaran 2020/2021. Hasil belajar peserta didik sebelum penerapan pembelajaran berbasis proyek (siklus I) sangat rendah, di mana diperoleh nilai ketuntasan klasikal hanya 33,3\%. Setelah dilakukan tindakan dengan menerapkan model pembelajaran berbasis proyek pada siklus II diperoleh nilai ketuntasan klasikal sebesar 90,5 \% dimana 19 orang peserta didik yang memperoleh nilai di atas KKM.

\section{Saran}

Saran yang dapat disampaikan berdasarkan hasil penelitian ini adalah; (1) Bagi guru diharapkan dapat menjadikan Model Pembelajaran Berbasis Proyek sebagai salah satu alternatif pembelajaran di kelas; dan (2) Perlu adanya penelitian lebih lanjut yang menggunakan sampel yang lebih luas sehingga keberhasilan model Pembelajaran Berbasis Proyek ini dapat teruji.

\section{Daftar Pustaka}

Abdiningsih, N. (2017). Upaya Meningkatkan Motivasi dan Hasil Belajar IPA Kelas VI Melalui Penerapan Model Dua Tinggal Dua Tamu di SD Negeri 3 Cakranegara. Jurnal Kependidikan: Jurnal Hasil Penelitian dan Kajian Kepustakaan di Bidang Pendidikan, Pengajaran dan Pembelajaran, 3(2). doi:https://doi.org/10.33394/jk.v3i2.676

Afriana, J., dan Fitriani, A. (2016). "Penerapan Project Based Learning Terintegrasi STEM Untuk Meningkatkan Literasi Sains Dan Kreativitas Siswa Ditinjau Dari Gender". Jurnal Inovasi Pendidikan IPA, 2(2): 202-212. 
Aminah, H. S. (2017). Peningkatan Hasil Belajar IPA melalui Model Kooperatif Tipe Jigsaw Berbantu Media Gambar Kelas IV SD. Jurnal Pendidikan Progresif, 7(2), 93-100.

Fikriyah, M., \& Gani, A. A. (2015). Model Pembelajaran Berbasis Proyek (Project Based Learning) Disertai Media Audio-Visual Dalam Pembelajaran Fisika Di Sman 4 Jember. Jurnal pembelajaran fisika, 4(2).

Fitriana, F. (2019). Penerapan Model Discovery Learning pada Pembelajaran IPA Materi Tekanan untuk Meningkatkan Hasil Belajar Siswa. Jurnal Kependidikan: Jurnal Hasil Penelitian dan Kajian Kepustakaan di Bidang Pendidikan, Pengajaran dan Pembelajaran, 5(2), 100-108. doi:https://doi.org/10.33394/jk.v5i2.1805

Iswantari, I. (2019). Meningkatkan Hasil Belajar Siswa Melalui Implementasi Model Pembelajaran Make A Match di SMP Negeri 2 Kayangan. Jurnal Kependidikan: Jurnal Hasil Penelitian dan Kajian Kepustakaan di Bidang Pendidikan, Pengajaran dan Pembelajaran, 5(2), 109-116. doi:https://doi.org/10.33394/jk.v5i2.1806

Lapase, M. (2021). Implementasi Pembelajaran Berbasis Proyek untuk Meningkatkan Hasil Belajar Siswa pada Mata Pelajaran Matematika di SD Negeri Pinedapa. Jurnal Paedagogy, 8(2), 134-143. doi:https://doi.org/10.33394/jp.v8i2.3492

Lestari, F. A. (2017). Meningkatkan Kemampuan Pemahaman Matematis Siswa Melalui Model Problem Based Learning (PBL)(Penelitian Quasi Eksperimen Terhadap Siswa SMP Negeri 1 Tambakdahan). Biormatika Jurnal Ilmiah FKIP Universitas Subang, 3(1), 1-8.

Mulyana, A. (2020). PENGERTIAN DAN SINTAKS MODEL PEMBELAJARAN BERBASIS PROYEK (PBP). JELAJAH INFORMASI.

Nashirotun, B. (2020). Peningkatan Aktivitas dan Hasil Belajar Siswa dengan Metode Jigsaw dan Media Tubuh Manusia pada Pembelajaran IPA di MTs. Negeri 4 Klaten Jawa Tengah. Jurnal Paedagogy, 7(4), 402-407. doi:https://doi.org/10.33394/jp.v7i4.2945

Pradita, Y., Mulyani, B., \& Redjeki, T. (2015). Penerapan model pembelajaran Project Based Learning untuk meningkatkan prestasi belajar dan kreativitas siswa pada materi pokok sistem koloid kelas XI IPA semester genap Madrasah Aliyah Negeri Klaten Tahun Pelajaran 2013/2014. Jurnal pendidikan kimia, 4(1), 89-96.

Purwati, N. (2019). Upaya Meningkatkan Motivasi dan Hasil Belajar IPA Siswa Melalui Penerapan Model Pembelajaran STAD di Kelas Vi SD Negeri 42 Mataram. Jurnal Paedagogy, 6(1), 14-19. doi:https://doi.org/10.33394/jp.v6i1.2525

Rati, N. W., Kusmaryatni, N., \& Rediani, N. (2017). Model pembelajaran berbasis proyek, kreativitas dan hasil belajar mahasiswa. JPI (Jurnal Pendidikan Indonesia), 6(1), 6071.

Santoso., E.B. 2013. Pengertian Kriteria Ketuntasan Minimal (KKM). Model Belajar.

Suarni, G., Rizka, M., \& Zinnurain, Z. (2021). Analisis Pengaruh Penerapan Model Pembelajaran Sains Teknologi Masyarakat Terhadap Hasil Belajar Siswa. Jurnal Paedagogy, 8(1), 31-38. doi:https://doi.org/10.33394/jp.v8i1.3226

Tilaar. (2001). Manajemen Pendidikan Nasional: Kajian Pendidikan Masa Depan. Bandung : PT Remaja Rosdakarya.

Wijanarko, A. G., Supardi, K. I., \& Marwoto, P. (2017). Keefektifan model project based learning terbimbing untuk meningkatkan keterampilan proses sains dan hasil belajar IPA. Journal of Primary Education, 6(2), 120-125. 